\title{
做心灵高雅的德育人
}

\author{
蒋芝芳 \\ 苏州工业园区青剑湖学校 \\ D O I:10.32629/jief.v2i1.449
}

[摘 要] 教师的责任是重大的, 教师的使命更是光荣的, 在教师播种的过程中, 要不断的学习, 用自己内在的教师修养润泽学生的成长, 用 自己内心的丰盈来为学生做好示范 , 用自己高雅的心灵做好教育育人的工作。

[关键词] 心灵高雅 ; 育人 ; 发展

在新时期下, 加强学生的德育教育工作对学生以及社会来说都具有 很重要的意义, 作为一名教师, 让每一位学生内心丰盈、品行高雅是教师 的神圣使命, 更是教师的职责。

老师是一种特殊的职业, 这种职业中有教师的爱, 放到教育里绵绵 不休得爱; 有教师的无限情感投入, 在教师生命里无法用言语来表述的教 育的情怀。教师的伟大之处, 不仅教书, 更在教书的路上育人。在教育之 路上人人都是德育人，教师就是心灵高贵的德育人。

谈到高贵，不同的人对高贵有着不同的理解，更喜欢李镇西的概括： 厚实的学问、儒雅的修养、执着的理想、赤诚的爱心、纯洁的童真、丰富 的智慧、宽阔的胸襟、凌云的气节、伟岸的风骨、朴素的良知、自由的精 神……构成了高贵心灵的全部内涵。努力做一个高雅的德育人, 不仅仅是 教师的情怀, 更是教师的教育责任。

1 尽职尽责，用爱铸就孩子们成长的路

一个人的生命是有长度的, 而爱是无止境的。作为教师我们要将师 爱延展在学生的生命力, 种在学生成长之路的每个脚印里。

每位教师都是学生生命成长的德育导师, 我们要有爱学生的能力, 同时也培养学生爱他人的能力。无论教师从事哪门学科教学, 在自己向学 生传授知识的同时, 都要不断地用期待、用鼓励、用激励来引领学生的成 长, 这是师爱的一种具体再现。爱是人类最美丽的语言, 当孩子遇到成长 的任何困惑的时候, 老师的一个微笑, 老师的一句关怀都是他们都走出烦 恼, 走进希望的有效力量, 教师的爱对学生的成长也是一种示范, 一种成 长的有效力量。“爱人者, 人恒爱之; 敬人者, 人恒敬之。” 作为教师无论 我们接触怎样的学生, 无论我们和怎样的家长对接, 都用这样的教育使命 来履行我们的教育职责, 我们在给学生、给他人爱的同时, 既幸福了他人, 也幸福了自己。无论我们教龄多长, 都会以最温暖的方式爱我们的学生, 让爱成为学生成长最好的催化剂, 真情流动, 让每个孩子感受到心灵的纯 净与润泽, 这是每个教师生命中最美好的记忆。

\section{2 用心陪伴, 给学生成长之路上最有利的指引}

生活总是在每个人不断地努力追求中前进的, 作为老师, 学校里我 们时刻和学生在一起。与他们在一起的过程中, 既要教会他们知识, 更要 引导他们做人。教师教书育人, 或许会遇到各种各样繁琐的事情, 工作是 辛苦的, 或许会有意想不到的困难, 但我们会不忘初心, 坚定而幸福的在 教育的伊甸园里不但耕耘、播种。

每个人的成长都不是一帆风顺的，在孩子不同的年龄阶段，不同的 成长时期都会遇到不同的问题, 学生的生命成长就是在不断地“遇到问题” 中长大的, 在不同的问题中得到提升的, 这个过程中因为他们年龄尚小, 缺少明辨是非的能力, 更缺少对生活的执着和认真的态度, 而教师就是为 他们成长助力的最好他人, 在学生需要的时候我们会以最恰当的方式与他 们一起走过每一道成长的坎坷, 走过成长的波折。

用心陪伴每个孩子的成长, 当学生遇到生活中的问题我们需要第一 时间了解; 当学生的学习遇到困惑时, 我们需要第一时间帮助解惑。教师
的陪伴无处不在, 不仅仅在学生取得成绩和成功的时候, 更在学生遇到问 题和成长障碍的时候, 给学生希望和信心, 给学生解决问题的办法和对策, 这是教师能给学生最好的陪伴。

3 智慧引领，让每个孩子都能够智慧成长

作为教师, 我们不仅是知识的传授者, 更是学生心灵的成长导师, 在他们成长的过程中, 需要用心的智慧引领, 才能够培养智慧的学生。

教育面临的对象是多样的, 甚至是多变的, 做一名德育引领者, 我 们要能够与时俱进, 要能够在不断的与书本学习、与同行学习、与他人学 习中不断地提升自己的教育技能, 只有在不断地学习中才能为学生提供最 好的教育, 提供最佳的教育成长。

首先教师要多研读一些教育专家的书籍, 在名家的教育智慧的指引 下不断地激发自己的教育潜能, 为学生提供最优质的教育引领。教师的读 书类别更要广泛, 博古通今, 中西合璧, 取他人所长。

无论是刚工作的教师还是有着丰富教育经验的教师, 都要为自己设立读 书计划, 多读一些和德育相关的书籍, 比如《班主任修心养德 100 篇签字妙 文》、《优秀班会课案例》, 从中积累德育方面的他人经验, 从中学习班主任工 作技巧, 丰富自己的育人经验。除此之外, 教师还要更多的读一些教师专业 成长的书籍, 比如《优秀教师的九堂必修课》、比如《教师工作方法创新案例 集》等书籍。通过这些书籍教师可以帮助我们从理论上汲取营养, 从他人的 实践中总结经验, 在自己的教学实践中反思, 将他人的经验与自己的教育实 践有机结合, 才能够智慧育人, 进而提升教育的生命和教育的质量。

我身边有一个榜样老师, 他每天坚持学习, 从读书开始, 纸质书、 电子书同时学习。学习之后会及时的将读书的心得书写下来, 并将读书中 的精髓用到自己的教育实践中, 不断地提升课堂的效率, 提升着对学生德 育的引领。做一个与时俱进的老师才能够给学生最优秀的教育, 做一个勤 思考的老师才能够给学生及时的提供教育所需, 由外而内, 从内而外的改 变学生, 浸润学生心灵, 提升学生的生命质量, 这也正是教师的价值。

“我们都在努力奔跑, 我们都是追梦人。”近平总书记在 2019 年新 年贺词中的话语, 激励教育人在追梦路上努力奔跑。在教育之路上我们更 应该积极的奋进, 用自己的学识洲博、用自己的无限师爱、用自己的无限 追求和理想成为每个孩子幸福的成长人生。

[参考文献]

[1]徐博.陶行知“四颗糖” 教育理念对职业学校德育教育的启示 [J]. 科学大众(科学教育),2020(02):136.

[2]再亚辉.学校德育不只需要温情, 也需要必要的强硬 $[J]$.中小学德 育,2020(02):5-8.

[3]刘敏知.儒法德育理念的比较及现实启示 [J].黑龙江教师发展学院 学报,2020,39(02):82-84.

作者简介: 蒋芝芳 (1988), 女, 汉族, 江苏苏州人, 大学本科, 一级教师, 研究方向 : 实践研究, 从事工作 : 小学数学。 